\title{
Article/Artigo
}

\section{Occurrence of dolichocolon without megacolon in chronic Chagas disease patients}

\author{
Ocorrência de dolicocólon sem megacólon em chagásicos crônicos
}

\author{
Cleudson Castro ${ }^{1}$, Esperanza Bernal Hernandez ${ }^{2}$, Joffre Rezende ${ }^{3,4}$ and Aluizio Prata ${ }^{\dagger}$
}

\begin{abstract}
Introduction: Since 1970, lengthening of the rectosigmoid has been suspected to be a solitary manifestation of Chagas colopathy. Methods: To test this hypothesis, opaque enema was administered on 210 seropositive and 63 seronegative patients, and radiographs in the anteroposterior and posteroanterior positions were examined blind to the serological and clinical findings. The distal colon was measured using a flexible ruler along the central axis of the image from the anus to the iliac crest. Results: Dolichocolon was diagnosed in 31 (14.8\%) seropositive and $3(4.8 \%)$ seronegative patients. The mean length was $57.2( \pm 12.2) \mathrm{cm}$ in seropositive patients and $52.1( \pm 8.8) \mathrm{cm}$ in the seronegative patients $(\mathrm{p}=0.000)$, that is, the distal colon in Chagas patients was, on average, $5.1 \mathrm{~cm}$ longer. Seropositive female patients presented a mean length of $58.8( \pm 12.3) \mathrm{cm}$, and seronegative female patients presented $53.2( \pm 9.1) \mathrm{cm}(\mathrm{p}=0.002)$. Seropositive male patients had a mean length of $55( \pm 11.6) \mathrm{cm}$, and seronegative male patients had $49.9( \pm 7.8) \mathrm{cm}(\mathrm{p}=0.02)$. Among 191 patients without megacolon and suspected megacolon, the mean length was $56.3( \pm 11.6) \mathrm{cm}$ in seropositive individuals and $52( \pm 8.8) \mathrm{cm}$ in seronegative patients $(\mathrm{p}=0.003)$. Among individuals with distal colon $\geq 70 \mathrm{~cm}$, there were 31 Chagas patients with mean length of $77.9( \pm 7.1) \mathrm{cm}$ and three seronegative with $71.3( \pm 1.1) \mathrm{cm}(\mathrm{p}=0.000)$. Among 179 with distal colon $<70 \mathrm{~cm}$, seropositive individuals had a mean length of $53.6( \pm 8.8) \mathrm{cm}$, and seronegative patients had $51.2( \pm 7.8) \mathrm{cm}$ $(p=0.059)$. Serological positive women had longer distal colon than men $(p=0.02)$, whereas the mean length were the same among seronegative individuals $(\mathrm{p}=0.16)$. Conclusions: In endemic areas of Brazil Central, solitary dolichocolon is a radiological Chagas disease signal. Keywords: Dolichocolon. Solitary dolichocolon. Chagas disease. Lengthening of the sigmoid. Length of the sigmoid.
\end{abstract}

\section{RESUMO}

Introdução: Desde 1970, suspeita-se que o alongamento do retossigmoide pode ocorrer como manifestação isolada da colopatia chagásica. Métodos: Para testar esta hipótese, 210 pacientes soropositivos e 63 soronegativos fizeram enema opaco e as radiografias nas posições ânteroposterior e póstero-anterior foram lidas sem conhecimento dos dados clínicos e sorológicos. O comprimento do cólon distal foi medido com curvímetro, percorrendo-se o eixo central da imagem, do ânus à crista ilíaca. Resultados: $\mathrm{O}$ diagnóstico de dolicocólon foi estabelecido em 31 $(14,8 \%)$ pacientes soropositivos e $3(4,8 \%)$ soronegativos. O comprimento médio nos pacientes soropositivos foi de $57,2( \pm 12,2) \mathrm{cm}$, enquanto nos soronegativos foi de $52,1( \pm 8,8) \mathrm{cm}(\mathrm{p}=0,000)$, isto é, os chagásicos apresentaram o cólon distal em média $5,1 \mathrm{~cm}$ maior. Os indivíduos do sexo feminino soropositivos exibiram comprimento médio de $58,8( \pm 12,3) \mathrm{cm}$, e os soronegativos de $53,2( \pm 9,1) \mathrm{cm},(\mathrm{p}=0,002)$. Nos pacientes do sexo masculino soropositivos, o comprimento médio foi de $55( \pm 11,6) \mathrm{cm}$, enquanto nos soronegativos foi de $49,9( \pm 7,8) \mathrm{cm}(\mathrm{p}=0,02)$. Nos 191 pacientes, sem megacólon e suspeitos de megacólon, o comprimento médio foi de $56,3( \pm 11,6)$ $\mathrm{cm}$ nos soropostivos e $52( \pm 8,8) \mathrm{cm}$ nos soronegativos $(\mathrm{p}=0,003)$. Dos indivíduos com cólon distal $\geq 70 \mathrm{~cm}$, os 31 chagásicos tiveram comprimento médio de $77,9( \pm 7,1) \mathrm{cm}$, enquanto nos três não chagásicos foi de $71,3( \pm 1,1) \mathrm{cm},(\mathrm{p}=0,000)$. Nos 179 com cólon distal $<70 \mathrm{~cm}$, os soropositivos tiveram em média $53,6( \pm 8,8) \mathrm{cm}$, e os soronegativos $51,2( \pm 7,8) \mathrm{cm},(\mathrm{p}=0,059)$. Dentre os com sorologia positiva, as mulheres apresentaram cólon distal maior que os homens $(\mathrm{p}=0,02)$, enquanto naqueles com sorologia negativa o comprimento médio foi igual $(\mathrm{p}=0,16)$. Conclusões: Nas áreas endêmicas do Brasil Central, o dolicocólon solitário é um sinal radiológico da doença de Chagas. Palavras-chaves: Dolicocólon. Dolicocólon solitário. Doença de Chagas. Alongamento do sigmoide. Comprimento do sigmoide.

1. Programa de Pós-Graduação em Medicina Tropical, Núcleo de Medicina Tropical, Universidade de Brasília, Brasília DF. 2. Unidade de Clínica Médica, Hospital do Paranoá, Secretária de Saúde do Distrito Federal, Brasília, DF. 3. Ex-Professor titular do Dept ${ }^{\circ}$ de Clínica Médica, Universidade Federal de Goiás, Goiânia, GO. 4. Professor Honoris Causa, Universidade de Brasília, Brasília, DF. †' In memorian.

Address to: Prof. Cleudson Castro. Dept ${ }^{\circ}$ de Clínica Médica/NMT/UnB. Caixa Postal 4517, 70904-970 Brasília, DF, Brasil.

Fax: $55613307-1154$

e-mail: cleudson@unb.br

Received in 06/06/2011

Accepted in 29/07/2011

\section{INTRODUCTION}

Carlos Chagas suspected that the digestive tract participated in the disease that came to bear his name ${ }^{1}$, through his acceptance that megaesophagus, common in areas that were endemic for Chagas disease, could be one of its manifestations. During the same era, Neiva and Pena observed hundreds of cases of megas on a journey through the interior of Brazil, especially in the State of Goiás ${ }^{2}$. Nevertheless, for a long time, Chagas disease and megas were considered to be different entities ${ }^{3}$. In the 1950s, Sabino Vieira de Freitas studied the two most important hypotheses relating to the likely etiology of megas (vitamin B1 deficiency and Chagas disease) and concluded reluctantly that the etiology still could not be established. He took the view that the link to Chagas disease was doubtful ${ }^{3}$. At that time, renowned professors thought that the two entities had different etiologies ${ }^{3}$.

At the Eighth Medical Congress of the Triângulo Mineiro and Central Brazil, held in Uberaba in 1956, Pedreira de Freitas declared that, despite the great reactions against accepting the link between megas and Chagas disease among Brazilian researchers, there already was a solid basis for establishing such a connection ${ }^{3}$. In 1955, Koeberle and Nador had established the pathogenetic basis for megaesophagus in Brazil ${ }^{4}$. In the following year, based on extensive clinical experience, Rezende $\mathrm{e}^{5}$ was the first to use the expression megaesophagus due to Chagas disease, and today, this knowledge has become well established. On the other hand, although megaesophagus and megacolon have been recognized as part of the clinical framework of American trypanosomiasis, solitary dolichocolon has not, and there are doubts about its pathological significance in patients who are serologically positive for Chagas disease. Currently, the terms dolichomegaesophagus and dolichomegacolon are well established and considered to be closely related to Chagas disease, but the term dolichocolon does not have the same connotation, and when it is solitary, it is considered to be of congenital nature. Specialized books only make passing reference to 
dolichocolon. The specific literature relating to dolichocolon is sparse, both in Portuguese and in English, and is limited to reports on cases associated with megacolon and Hirschprung's disease and, more rarely, to cases of acquired dolichocolon of uncertain cause. The aim of the present study was to present radiological and statistical data that favor including cases of solitary dolichocolon as part of Chagas disease.

\section{METHODS}

\section{Patients studied}

This radiological study was conducted between May 2000 and August 2001 among the population in the municipality of Mambaí, State of Goiás, which is an area endemic for Chagas disease. A list of individuals within the Mambaí project was prepared and handed over to the physician who was coordinating the work in the municipality. This physician was unaware of the clinical and serological status of the patients. The patients included were adults with six serologically positive reactions for Chagas disease who presented the indeterminate, cardiac, or digestive form of the disease and individuals with six negative serological reactions who had constipation as a symptom. Cases of severe cardiopathy and pregnancy were excluded. The task of locating the patients was undertaken by a health agent who lived in the municipality and had been working in the project since 1975 . The patients were transported by car from their homes to Damianópolis, and an average of six examinations per day was performed. At the hospital, before undergoing the examination, the patients answered a standard questionnaire that sought identification, age and sex data, and information on the symptom of constipation.

\section{Radiological study and parameters}

The test used was opaque enema, by means of the method recommended by Ximenes et al. ${ }^{6}$, with small modifications that, in brief, did away with colon preparation and introduced air for double contrast. The examinations were performed in the municipality of Damianópolis, which is a town $18 \mathrm{~km}$ from the main settlement of Mambaí that had an X-ray machine appropriate for the procedure. A radiology technician with experience of performing opaque enemas went from Brasília to train the technician who was based in Damianópolis, and they carried out the first examinations together. Wearing a hospital gown, the patients were positioned in dorsal decubitus on the X-ray table, and a simple radiograph of the abdomen was produced first to rule out the presence of fecaloma. Immediately before the examination, a suspension of $150 \mathrm{ml}$ of barium sulfate in $1,000 \mathrm{ml}$ of water was prepared. The enema was applied with the patient in the left lateral decubitus, and the receptacle containing the contrast medium was positioned $1.5 \mathrm{~m}$ above the plane of the examination table. Two radiographs were produced, in anteroposterior and posteroanterior views, at 80 to 100 kilovolts and 0.30 to 0.40 milliamperes (mAs). The films were developed immediately after the examinations. The time taken to carry out one examination, from administering the questionnaire to producing the radiographs, was approximately $40 \mathrm{~min}$. The radiographs were taken to Goiânia and interpreted by one of the authors (JR), who was unaware of the patients' data. The interpretation was performed by visual observation of the radiographs on an X-ray film viewer and by measuring the length of the distal colon, which was taken here to mean the sigmoid loop, rectum, and anal canal. According to Testut's Anatomy ${ }^{7}$, the length of the rectum in adults ranges from 12 to $15 \mathrm{~cm}$, and that of the sigmoid loop is from 30 to 50 . Thus, measurements on the segment from the sigmoid loop to the rectum range between 42 and $65 \mathrm{~cm}$. After adding 2 to $3 \mathrm{~cm}$ for the anal canal, the total length of the distal colon, from the anus to the transition to the descending colon, reaches 45 to $68 \mathrm{~cm}$. This measurement was made using a flexible ruler, which was laid out along the central axis of the radiological image in the ascending direction, going from the anus to the level of the left iliac crest. The measurement obtained had relative value because of the irregular and variable layout of the sigmoid loop, which included segments going in an anteroposterior direction, thereby diminishing their length on the radiological projection. Lengths greater than or equal to $70 \mathrm{~cm}$ were defined as dolichocolon.

\section{Statistical analysis}

The information was stored in a database. The analysis was carried out with the aid of the SPSS software, version 9.0, for Windows. For all the tests used, the significance level was set at less than 0.05 . Student's $t$ test was used to determine the significance of differences that were found in the means of the quantitative variables.

\section{Ethical considerations}

The population of Mambaí had been undergoing tests since 1974. This project was approved by the ethics committee of the School of Health Sciences, University of Brasília (UnB), and was conducted in accordance with the standards of Resolution 196/96. The aims of the study and the type of examination that would be performed were explained to each patient. Written consent was requested, and the examinations were only carried out after receiving the patients' agreement. Patients who needed specialized treatment were referred to the University Hospital of Brasília. During the study period, the population was attended at a health clinic maintained through the project.

\section{RESULTS}

Of the 303 individuals who were examined radiologically, 30 were excluded: four had no available serological tests, two had doubtful serological tests, and 24 had distal colon length that was impossible to measure. Thus, 273 patients were evaluated, of whom, 210 were seropositive for Chagas disease, and 63 were seronegative. The patients' ages ranged from 27 to 87 years; the mean age of the patients examined was $48.9 \pm 12.4$ years, and the mean age of the seropositive patients was $49.3 \pm 12.4$ years.

The radiographs were analyzed by one of the authors (JR), who was unaware of the patients' serological and clinical status. In addition to visual analysis of the radiographs on an X-ray film viewer, the largest diameters of the rectum and sigmoid ${ }^{8}$ and the length of the distal colon were measured. To make these measurements, preference was given to anteroposterior radiographs, whereas posteroanterior views were only used when no measurement could be obtained using the anteroposterior view.

Analysis on the data showed that the mean length of the distal colon among the infected patients was $57.2 \pm 12.2 \mathrm{~cm}$ and that this differed from that of the patients without infection $(52.1 \pm 8.8 \mathrm{~cm}$; $\mathrm{p}=0.000$ ), as can be seen in Table 1. Thus, the patients with Chagas disease had distal colons that were, on average, $5.1 \mathrm{~cm}$ longer than 
TABLE 1 - Mean length of the distal colon in centimeters, in patients with and without Chagas disease.

\begin{tabular}{|c|c|c|c|c|c|c|c|c|}
\hline \multirow[b]{2}{*}{ Mean length } & \multicolumn{3}{|c|}{$\begin{array}{c}\text { With Chagas } \\
\text { disease }\end{array}$} & \multicolumn{3}{|c|}{$\begin{array}{c}\text { Without Chagas } \\
\text { disease }\end{array}$} & \multirow[b]{2}{*}{$\mathbf{t}$} & \multirow[b]{2}{*}{$\mathbf{p}$} \\
\hline & $\mathbf{n}$ & lngt & se & $\mathbf{n}$ & lngt & se & & \\
\hline Population examined & 210 & 57.2 & 12.2 & 63 & 52.1 & 8.8 & 3.63 & 0.000 \\
\hline female & 120 & 58.8 & 12.3 & 43 & 53.2 & 9.1 & 3.16 & 0.002 \\
\hline male & 90 & 55.0 & 11.6 & 20 & 49.9 & 7.8 & 2.38 & 0.022 \\
\hline Without megacolon & 191 & 56.3 & 11.6 & 61 & 52.0 & 8.8 & 3.06 & 0.003 \\
\hline With megacolon & 13 & 62.5 & 12.0 & - & - & & & \\
\hline Suspected megacolon & 6 & 72.5 & 17.4 & 2 & 56.0 & 7.1 & 1.25 & 0.257 \\
\hline Distal colon $\geq 70 \mathrm{~cm}$ & 31 & 77.9 & 7.1 & 3 & 71.3 & 1.1 & 4.54 & 0.000 \\
\hline Distal colon $<70 \mathrm{~m}$ & 179 & 53.6 & 8.8 & 60 & 51.2 & 7.8 & 1.89 & 0.059 \\
\hline
\end{tabular}

$\mathbf{n}$ : number of patients; lngt: length; se: standard error; t: Student's t test; p: probability.

those of the noninfected patients. Among the female patients, analysis on the mean length of the distal colon showed that the women with Chagas disease had distal colon that were longer $(58.8 \pm 12.3 \mathrm{~cm})$ than those of the noninfected patients $(53.2 \pm 9.1 \mathrm{~cm} ; \mathrm{p}=0.002)$. Thus, the women with Chagas disease had distal colons that, on average, were $5.6 \mathrm{~cm}$ longer than those of the non-infected patients. This also was noted in relation to the mean length of the distal colon in the men: those with Chagas disease had a mean length of $55 \pm$ $11.6 \mathrm{~cm}$, whereas the length in the noninfected men was $49.9 \pm 7.8 \mathrm{~cm}$ $(\mathrm{p}=0.02)$. Thus, the men with Chagas disease presented distal colons that, on average, were $5.1 \mathrm{~cm}$ longer than those in men without infection. After subtracting 13 patients with evident megacolon and another six with megacolon suspected from the visual inspection (19 patients) from the total of 273 patients, the mean measurement among the remaining 191 seropositive patients was $56.3 \pm 11.6 \mathrm{~cm}$, and that among the 61 seronegative patients was $52 \pm 8.8 \mathrm{~cm}$ $(\mathrm{p}=0.003)$. Therefore, after excluding the Chagas patients with a dilated colon, the remainder presented a distal colon that was, on average, $4.3 \mathrm{~cm}$ longer than that among the noninfected patients.

The mean length of the distal colon in individuals of different genders varied according to the serological status for Chagas disease. Among the seropositive individuals, female distal colons were significantly longer $(58.8 \pm 12.3 \mathrm{~cm})$ than male distal colons $(55 \pm 11.6 \mathrm{~cm} ; \mathrm{p}=0.02)$. Among the seronegative individuals, the female distal colon continued to be longer $(53.2 \pm 9.1 \mathrm{~cm})$ than the male distal colon $(49.9 \pm 7.8 \mathrm{~cm})$ but without statistical significance $(\mathrm{p}=0.16)$ (Table 2).

Of the 34 patients with dolichocolon, 31 had Chagas disease, and their mean distal colon length was $77.9 \pm 7.1 \mathrm{~cm}$, whereas among the three individuals without Chagas disease, it was $71.3 \pm 1.1 \mathrm{~cm}$ $(\mathrm{t}=4.54 ; \mathrm{p}=0.000)$. The difference was significant, that is, the Chagas dolichocolon was, on average, $6.6 \mathrm{~cm}$ longer.

TABLE 2 - Mean length of the sigmoid loop, rectum, and anal canal, in centimeters, in relation to gender and serological status for Chagas disease.

\begin{tabular}{|c|c|c|c|c|c|c|c|c|}
\hline \multirow[b]{2}{*}{ Serological status } & \multicolumn{3}{|c|}{ Male } & \multicolumn{3}{|c|}{ Female } & \multirow[b]{2}{*}{$\mathbf{t}$} & \multirow[b]{2}{*}{$\mathbf{p}$} \\
\hline & $\mathbf{n}$ & lngt & se & $\mathbf{n}$ & lngt & se & & \\
\hline Positive & 90 & 55.0 & 11.6 & 120 & 58.8 & 12.3 & 2.28 & 0.02 \\
\hline Negative & 20 & 49.9 & 7.8 & 43 & 53.2 & 9.1 & -1.39 & 0.16 \\
\hline
\end{tabular}

n: number of patients; lngt: length; se: standard error; t: Student's t test; p: probability.
After excluding the patients with distal colons measuring $70 \mathrm{~cm}$ or longer, the remaining patients consisted of 179 seropositive individuals, with a mean distal colon length of $53.6 \pm 8.8 \mathrm{~cm}$, and 60 seronegative individuals, with a mean length of $51.2 \pm 7.8 \mathrm{~cm}$ $(\mathrm{p}=0.059)$. In this analysis, the distal colon in the Chagas patients was, on average, $2.4 \mathrm{~cm}$ longer, with a strong trend toward having a longer intestinal segment but without statistical significance.

Among the 31 seropositive patients with dolichocolon, the longest measurement was $100 \mathrm{~cm}$, whereas among the three seronegative patients with dolichocolon, the longest measurement was $72 \mathrm{~cm}$. Among the seropositive individuals, there were five with dolichomegacolon and four with possible megacolon. Among the 24 individuals for whom measurement of the distal colon was impossible, 15 were seropositive, and nine were seronegative (Table 3 ).

TABLE 3 - Results from radiological examinations on the colon among patients known to have the acute form of Chagas disease, in different places, and over different lengths of evolution.

\begin{tabular}{lcccccc}
\hline & \multirow{2}{*}{$\begin{array}{c}\text { Examinations } \\
\text { Locality }\end{array}$} & Years of & \multicolumn{3}{c}{ Colon $(\%)$} \\
\cline { 5 - 6 } & $(\mathbf{n})$ & 3.1 & 100.0 & 0.0 & 0.0 \\
\hline Bahia & 16 & 8.1 & 78.1 & 15.6 & 6.3 \\
Uberaba & 32 & 11.1 & 88.4 & 5.8 & 5.8 \\
Goiânia & 17 & 17.0 & 71.6 & 14.7 & 13.7 \\
Bambuí & 95 & & & & \\
\hline
\end{tabular}

\section{DISCUSSION}

Summary data from this investigation were published in $2003^{9}$, and the data are detailed in the present study. The specific literature relating to dolichocolon in Brazilian gastroenterological publications is sparse. In other Latin American publications, dolichocolon is mentioned in connection with studies on Chagas disease and megacolon ${ }^{10-13}$. When dolichocolon appears as the only radiological finding, it has been considered to be of congenital origin or unknown cause. When diagnosed in individuals who are seropositive for Chagas disease, there is some doubt regarding the true cause, although data allowing linkage with American trypanosomiasis exist. Since 1970, when a group of Brazilian researchers presented information regarding the evolution of Chagas disease ${ }^{10}$, at a congress in Porto Alegre, it has become possible to link dolichocolon to Chagas disease from the data presented. In Table 3, which summarizes the findings from this investigation, it can be seen that the lengthening of the colon occurs more frequently than does megacolon ${ }^{10}$. Dias ${ }^{11}$ reinforced the impression that dolichocolon is the initial stage of Chagas colopathy, and Rezende et al. ${ }^{14}$ brought in new support through radiological imaging measurements from an opaque enema that showed that the mean length of the distal colon in Chagas patients without megacolon was greater than that in seronegative controls.

Among the 273 patients examined in the present study, 34 (12.5\%) presented dolichocolon, among whom, 31 (14.8\%) were seropositive, and 3 (4.8\%) were among the 63 seronegative individuals in this study. Also, among these individuals, 14 (6.2\%) cases of megacolon or dolichomegacolon were diagnosed ${ }^{8}$. This higher prevalence of dolichocolon, in relation to megacolon or dolichomegacolon, provides a strong indication that lengthening precedes dilatation. There were more than twice as many cases of dolichocolon in relation to megacolon. Compared with megacolon, dolichocolon is more silent, and it is not known whether it causes 
constipation, although Dias ${ }^{11}$ observed that patients in the Bambuí project were symptomatic. There are no data on the symptom of constipation among patients exclusively presenting dolichocolon.

Recent studies have taken up this topic again, with large samples, thereby reinforcing the opinion of Rezende et al. ${ }^{14}$. The data from the present study and those obtained by Lopes ${ }^{15}$ point in this direction. In the study by Lopes ${ }^{15}$, all the 72 patients with megacolon presented lengthening of the rectosigmoid. All the patients with a possible diagnosis of megacolon presented rectosigmoid length greater than the established limits, and the median rectosigmoid length among the Chagas patients without megacolon was significantly greater than among the non-Chagas individuals ${ }^{15}$.

All the indications are that the morphological changes to the colon occur at a time that differs from when the changes to the esophagus occur. In the esophagus, the lengthening appears at the end (in megaesophagus group IV), whereas in the colon, it is the first change and precedes megacolon.

Pathological anatomy does not seem to be an adequate method for studying the lengthening of the rectosigmoid. Adad ${ }^{16}$ studied surgical and necropsy specimens from individuals with unquestionable clinical and radiological diagnoses of Chagas colopathy and did not find any difference in sigmoid length between Chagas patients and seronegative controls. Even when dealing with organs that have been radiologically defined as dolichomegacolon, pathologists are often unable to confirm the diagnosis ${ }^{16}$.

The present study was conducted blindly by a single local team that did not know the results from the serological tests, and the radiographs were analyzed and measured by a researcher $500 \mathrm{~km}$ away, who did not know anything about the patients.

The diagnosis of dolichocolon is essentially radiological. Assessment of the image by a radiologist or clinician seals the diagnosis even in the absence of symptoms. According to Lopes ${ }^{15}$, who is a radiologist, the feature that draws attention most in the diagnosis is the lengthening of the rectosigmoid. He did not make any distinction between dolichocolon and dilatation of the colon and considered both to be megacolon, within the concept of the greater colon. In his view, megacolon mostly starts with lengthening of the sigmoid, whereas the lengthening is associated with increasing diameter at advanced stages. The present study demonstrated that even among individuals with distal colon length within the normal maximum limit (i.e., less than $70 \mathrm{~cm}$ ), those with American trypanosomiasis present a strong tendency to have longer distal colons than seen in seronegative controls.

Old autopsy and radiological studies conducted outside Latin America revealed that dolichocolon or redundant colon was found in 14 to $16 \%$ of the population ${ }^{17}$. To the best of our knowledge, such data do not exist in Brazilian settings, where Chagas disease predominates. With the exception of Andean dolichocolon ${ }^{18}$, which is found in the Andes Mountains above the altitude of $3,000 \mathrm{~m}$ and is attributable to dietary causes, it is possible that on endemic areas in Latin America, the main cause of solitary dolichocolon is Chagas disease.

In conclusion, the study conducted in the $1970 \mathrm{~s}^{10}$, the information from Dias ${ }^{11}$ relating to the Bambuí project, the study by Rezende et al. ${ }^{14}$ on patients in hospitals in Goiânia, the data from the present study obtained from Mambaí, and the study by Lopes in Uberaba ${ }^{15}$ constitute a robust data set that, in endemic areas of Brazil Central, qualify solitary dolichocolon as a legitimate component of Chagas disease.

\section{CONFLICT OF INTEREST}

The authors declare that there is no conflict of interest.

\section{REFERENCES}

1. Chagas C. Trypanosomiase americana. Forma aguda da moléstia. Mem Inst Oswaldo Cruz 1916; 8:37-60.

2. Neiva A, Pena B. Viagem cientifica pelo norte da Bahia, sudoeste de Pernambuco, sul do Piauhi e de norte a sul de Goiás . Mem Inst Oswaldo Cruz 1916; Tomo III fasc 3:75-224.

3. Porto C, Porto CC. Historia do megaesôfago nos congressos no Brasil Central. Rev Goiana Méd 1970; 16:117-136.

4. Koeberle F, Nador E. Etiologia e Patogenia do megaesôfago no Brasil. Rev Paulista Med 1955; 47: 643

5. Rezende JM. Megaesôfago por doença de Chagas. Rev Goiana Med 1956; 2:297-314

6. Ximenes CA, Rezende JM, Moreira H, Vaz MGM. Técnica simplificada para diagnóstico radiológico do megacólon chagásico. Rev Soc Bras Med Trop 1984; 17 (supl): 23.

7. Testut L. Traité D’anatomie humaine, $8^{\circ}$ ed. Paris: Gaston Doien \& Cie; 1931.

8. Castro C, Hernandez EB, Rezende J, Prata A. Estudo radiológico do megacólon em área endêmica de doença de Chagas. Rev Soc Bras Med Trop 2010; 43:562-566.

9. Hernandez EBR, Rezende JM, Macedo V, Castro C. Estudo radiológico do cólon através da técnica de Ximenes em área endêmica de Chagas: prevalência de dolicocólon. Rev Soc Bras Med Trop 2003; 36 (supl II):73-74.

10. Prata AR, Dias JCP, Ferreira HO, Rassi A, Macedo VO, Rezende JM, et al. Grupo de estudos sobre a evolução da doença de Chagas. Porto Alegre: Resumos do VI Congresso da Sociedade Brasileira de Medicina Tropical; 1970.

11. Dias JCP. Doença de Chagas em Bambuí Minas Gerais, Brasil. Estudo clínico epidemiológico a partir da fase aguda, entre 1940 e 1982. [Tese de doutorado]. [Belo Horizonte]: Universidade Federal de Minas Gerais; 1982.376 p.

12. Calderon C, Aldana M. Estudio del colon en pacientes chagasicos asintomaticos y sintomaticos. Parasitol al Dia 1987; 11:65-71.

13. Calderon C. Estudios digestivo y cardiologico simultaneos en pacientes chagasicos asintomaticos. Rev Med Chile 1992; 120:43-47.

14. Rezende JM, Ximenes CA, Moreira H, Vaz MGM, Luquetti AO. Alongamento do cólon distal em pacientes com a forma digestiva da doença de Chagas. Paper presented at: Resumos do XXXI Congresso Brasileiro de gastroenterologia e VII Congresso Brasileiro de Endoscopia digestiva; Belém, Brazil; 1990.

15. Lopes GP. Estudo radiológico do comprimento e calibre do retosigmóide em pacientes chagásicos e em controles procedentes de diferentes altitudes. [Dissertação de Mestrado]. [Uberaba]: Universidade Federal do Triângulo Mineiro; 2003. 86 p.

16. Adad SJ. Contribuição ao estudo da anatomia patológica e patogênese do megacólon chagásico. [Doctor Dissertation]. [Uberaba]: Faculdade de Medicina do Triângulo Mineiro; 1996. 212 p

17. Bockus HL. Developmental anomalies of the colon. In: Bockus HL, editor. Gastroenterology. Vol II. Saunders: Company; 1949. p. 391

18. Franco FE. El colon íleo-pelvico en los peruanos. [Doctor Dissertation]. [Lima]: Universidad Nacional Mayor de San Marcos; 1965 